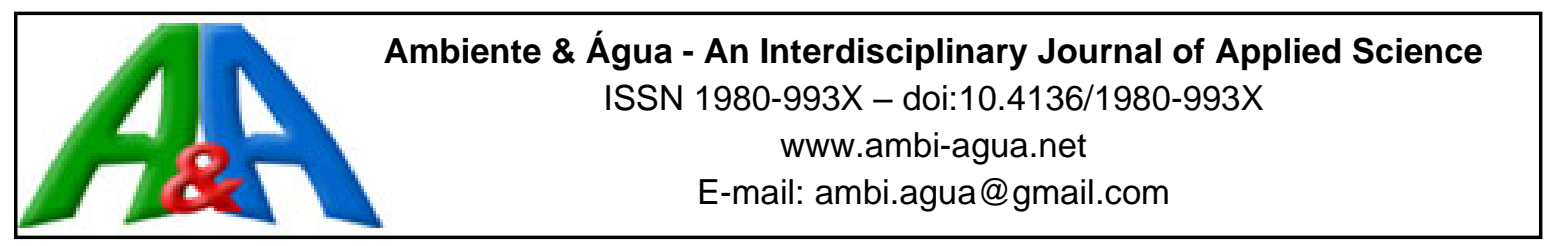

\title{
Sustainable provision of raw water based on the management of ecosystem services in small watersheds
}

\author{
ARTICLES doi:10.4136/ambi-agua.2439
}

Received: 05 Jul. 2019; Accepted: 26 Jan. 2020

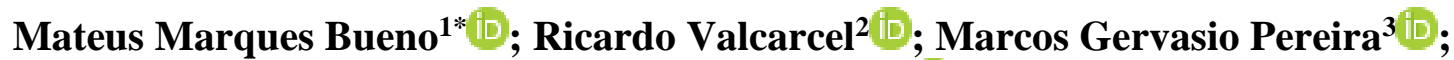 Felipe Araújo Mateus ${ }^{2}$ ic}

\author{
${ }^{1}$ Departamento de Agronomia. Instituto Federal de Educação de Minas Gerais (IFMG/SJE), \\ Avenida Primeiro de Junho, $n^{\circ}$ 1043, CEP: 39705-000, São João Evangelista, MG, Brazil. \\ ${ }^{2}$ Departamento de Ciências Ambientais. Instituto de Florestas. Universidade Federal Rural do Rio de Janeiro \\ (UFRRJ), Rodovia BR 465, Km 07, s/n, CEP: 23890-000, Seropédica, RJ, Brazil. E-mail: \\ ricardo.valcarcel@gmail.com, felipearaujomateus@gmail.com \\ ${ }^{3}$ Departamento de Solos. Instituto Agronomia. Universidade Federal Rural do Rio de Janeiro (UFRRJ), Rodovia \\ BR 465, Km 07, s/n, CEP: 23890-000, Seropédica, RJ, Brazil. E-mail: mgervasiopereira01@ gmail.com \\ "Corresponding author. E-mail: mateus.bueno@ifmg.edu.br
}

\begin{abstract}
The differentiated effects of the provision of environmental services in a watershed are due to the capacity of regularization of outflows in its mouth. In impacted areas, this environmental function is affected, and in some situations, it ceases to exist completely. This study characterized the soil and the production of sediments in anthropic watersheds, with the purpose of describing and evaluating the environmental services offered by a watershed undergoing anthropic transformation. The analyses show that the water flow in the remaining watersheds was preferably horizontal in the transmission zone, and these areas represent almost all areas. The values of hydraulic conductivity suggest that the infiltration decreases with soil depth; this fact is corroborated by the values of bulk density. The natural regions of water accumulation, the floodplains or outcrops zones, are small and do not have direct contact with the main floodplain present in the Guandu River Basin, making it impossible to recharge through other areas. Even so, water balance shows that the set of measures implemented ensured that the deficit water demand was supplied during the years of operation, even in times of water deficit. Likewise, the retention of solids in the settling tanks and in the drainage system prevented some 29,000 $\mathrm{t}$ of sediment from being carried between the years of 2012 and 2015.
\end{abstract}

Keywords: hydric balance, sediments, water resources.

\section{Produção sustentável de água bruta baseado no manejo dos serviços ecossistêmicos de microbacias}

\section{RESUMO}

Os efeitos diferenciados da produção de serviços ambientais em microbacias se devem à capacidade de regularização das vazões de saída em seu exutório. Já em áreas impactadas esta função ambiental é afetada e, em algumas situações, deixa de existir completamente. Este estudo objetivou caracterizar o solo e a produção de sedimentos em microbacias antropizadas, com o intuito de descrever e avaliar os serviços ambientais oferecidos por uma bacia em transformação antrópica. As análises mostram que o fluxo hídrico nas microbacias remanescentes eram, preferencialmente, horizontais na zona de transmissão, que representa 
quase a totalidade das áreas. Os valores de condutividade hidráulica, sugerem que a infiltração diminui em profundidade, este fato é corroborado pelos valores de densidade do solo. As regiões naturais de acúmulo de água, as várzeas ou zonas de afloramento, são pequenas e não possuem recarga por outras áreas. Mesmo assim, balanço hídrico mostra que o conjunto de medidas implementadas garantiu que a demanda hídrica deficitária fosse suprida ao longo dos anos de funcionamento, mesmo em época de déficit hídrico. Da mesma forma, a retenção de sólidos nos tanques de decantação e no sistema de drenagem, impediu que cerca de $29.000 \mathrm{t}$ de sedimentos fossem carreados entre os anos de 2012 a 2015.

Palavras-chave: balanço hídrico, recursos hídricos, sedimentos.

\section{INTRODUCTION}

The differentiated effects of the pro environmental services in watersheds, because of the hydrologically sensitive effects, can be measured by their ability to regularize the flow of the river basin. Under natural conditions, the watersheds have the capacity to produce water, thus contributing to the sustainable development of their environment. They control the exchange of water and related chemical flows from the upper catchment area to surface waters like streams and lakes (Hattermann et al., 2006).

In impacted areas, the ecosystem function of water provision can be affected, depending on the type of use and the intensity of that use, as well as the modifications of the soil attributes.

Commonly, water is produced in the flat and high areas of watersheds and stored in outcrop areas or natural reservoirs. These reservoirs may present small individual capacity; however, when all the contributions are united, the local water regime is created. Barban (2009) argues that natural reservoirs must be interrelated and, therefore, they must be appropriately interlinked with sectoral policies established by the government water management practices. Thus, the diagnosis of the conditions of the small watersheds and the impacts they endure should guide the measures to provide water.

This differentiation is due both to the large amplitude in the precipitated volume during the year and to the effect of the sea and rivers, especially in the lowlands. In this sense, the irregular exploitation of the soil, combined with the increase in temperature and the irregular distribution of rainfall, increase the variation of water production capacity within the same watershed (Gnadlinger, 2014).

In addition, the correct identification of key elements of watershed ecosystems services allows a series of measures to be applied in order to enhance a desired service, such as water production. This correct identification will guarantee the increase of water storage inside the watershed and, consequently, the reduction of surface water loss. In this way, the integrated management of watersheds and ecosystems, although distinct, must converge towards the same end (Cook and Spray, 2012).

Therefore, the provision of water in a watershed depends on the natural capacity of the area and local climate, but it is possible that occasional changes may increase this capacity. This study was developed in a small group of watersheds, where an industrial project with high demand for water resources is leased, with a low capacity to offer them naturally. The study characterized the soil and the production of sediments in the watershed, in order to describe and evaluate the environmental services offered by a watershed undergoing anthropic transformation.

\section{MATERIALS AND METHODS}

The study (Figure 1) was carried out in a Group of Small Watersheds (GMH), which were classified as watersheds not only for their size, but also for their hydrological functions, 
especially the characteristic of allowing the measurement of actions in their area, such as heavy rainfall and changes in soil cover (Teodoro et al., 2007). There is mining in operation in these areas. The total area of the watersheds is 73.37 ha. This area was in the eastern center portion of the Guandu System (BHSG), in Queimados, RJ. The central coordinate of the study area is $22^{\circ} 43^{\prime} 49.82^{\prime \prime} \mathrm{S}$ and $43^{\circ} 32^{\prime} 43.87^{\prime \prime} \mathrm{W}$.

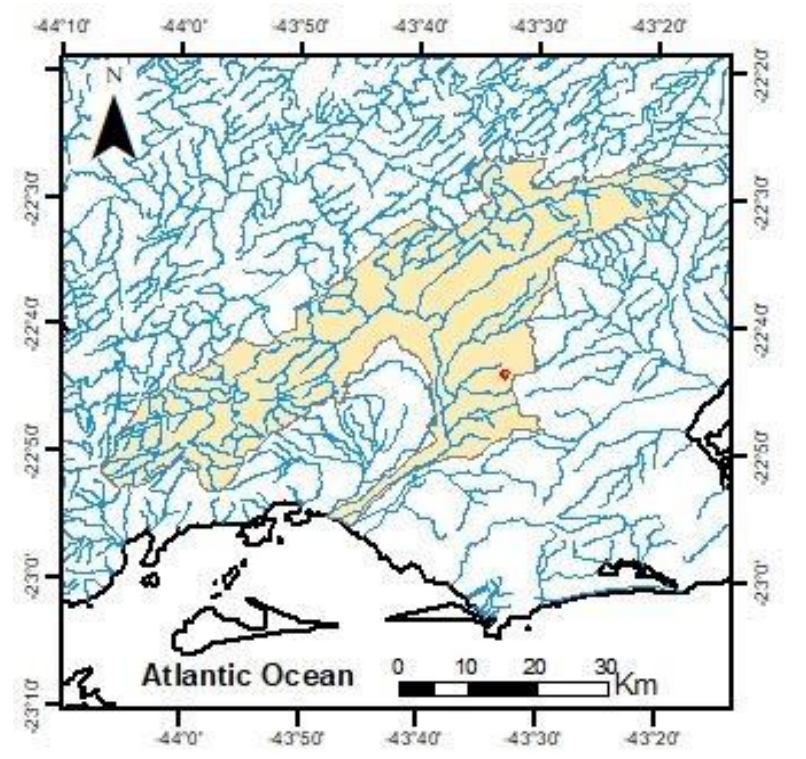

\section{Legenda}

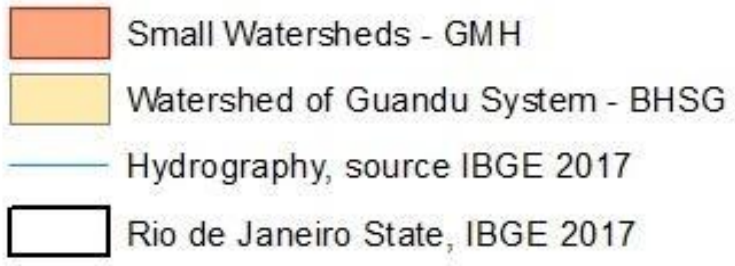

Figure 1. Location of Guandu Watershed System (BHSG) and the Small Watersheds (GMH) were ecosystem management actions were carried out.

The predominant climate in the region is Aw de Köppen (Alvares et al., 2013). The rainfall regime is characterized by a rainy season, from December to March (summer), and dry season, from June to August (winter). The average annual precipitation is $1,270 \mathrm{~mm}$; however, the configuration of the relief, given that the GMH are located at the northwest of the geographic mass called Madureira Mendanha, combined with the predominant air currents (Atlantic tropical - mTa), make the average rainfall lower in this area than it is in the BHSG. Local rainfall, temperature and wind speed data were obtained from an ION-1090-WH meteorological station installed in the experimental area. The total annual average precipitation for the station installed in the experimental area and in the year 2016 was $700 \mathrm{~mm}$.

The activity developed in this study is the complete transformation of the landscape, removing all soil demand, as well as the rocks, which are processed using water. The flow demanded by the production system depends on the volume of production and the climatic conditions. Thus, higher water demand occurs when there is a lower supply, which is during the dry season. On average, the daily consumption projected for the entire production system, running 24 hours a day, is $40 \mathrm{~m}^{3}$ of water.

With respect to water provision, the ecosystem service offered in the study area is restricted to small areas of outcrop, as related by Bueno et al. (2019). Thus, water supply and sediment production were applied by means of a water balance and by measuring the volume of sediment that left the system. In addition, the water-flow pattern was described in the different hydrogenetic zones, as proposed by Bueno et al. (2019), through the local relief and description of soil profiles.

In general, environmental service-enhancing practices were aimed at reducing evapotranspiration losses and increasing the volume of water in the subsurface aquifer, in addition to allowing the circulation of the water surplus. This system allowed the precipitated water to be directed to the outcrop areas and stored. Subsequently, part of this volume was pumped into a passing box system, then transferred to an Australian tank where it was then 
used. Finally, the unused portion was returned to the drainage system, returning to the storage system.

The total period of study was from 2011 to 2016. In 2011, secondary data were collected to prepare the initial water balance, to diagnose the study area before the start of mining activities. In the following years, 2012 to 2014, the implantation and evaluations of the mitigating measures were carried out. The field tests and analyses, described in the sequence, were carried out in the years of 2015 and 2016.

The GMH morphometric characterization was based on physiographic parameters and drainage patterns classified according to Christofoletti (1980). The physical parameters of the GMH (area, perimeter, channels' lengths, drainage density, form factor, index of circularity [Ke], compactness index [Kc], and sinuosity index [Is]) were computed as described by the methodology of Hajam et al. (2013). The database, with the available environmental information (elevation data, political and geographic boundaries, thematic maps, satellite images) was obtained through the processing of the digital cartographic base from the Brazilian Institute of Geography and Statistics (IBGE), with equidistant $10 \mathrm{~m}$ level curves, hydrography and quoted points, at the 1:25,000 scale.

The GMH soil characterization was made in the remaining areas (out of the mining pit), in the hydrogenetic zones named: capitation, transmission and outcrop. At these points, trenches were opened to describe soil profiles and the collection of deformed samples with dutch traces was carried out and the samples were collected using the Uhland collector. The depths of samples were: $15 \mathrm{~cm}, 40 \mathrm{~cm}$ and $70 \mathrm{~cm}$. For each collection point, 3 replications were performed. In the laboratory, the chemical and granulometric characterization was carried out according to Donagema et al. (2011). The hydraulic conductivity measurement was performed through a constant-load permeameter. The macro- and micro porosity were determined by means of the tension table, and the soil bulk density was determined using the volumetric balloon method of Donagema et al. (2011). In addition, the measurement of soil depth was evaluated along the remaining areas and progress of the soil in order to qualify the storage capacity and the predominant water flows.

Soil water storage systems were constructed in each of the watersheds. These areas, with functions like outcrop zones, were maintained and potentialized through the construction of underground dams. In the center of each storage area was constructed a shallow well, from which the water was collected, initially destined for a reservoir, and later, for different uses. This measure allied to the drainage system allows the circulation of water in the system.

The runoff flow was obtained from the measurement of the maximum height values of the drainage channel and correlation with the catchment area, individually for each small watershed, and added to obtain the total flow of the GMH. The total volume of sediments of lower particle size was obtained by multiplying the mean sediment concentration and estimated total flow.

Throughout the drainage and water storage system, small sedimentation wells were designed, and at strategic points, larger wells, in order to facilitate the infiltration of water into the soil. Whenever possible this system was in contact with the original terrain, pouring water infiltrated to the natural drainage of the small watersheds.

The quantity of sediments that leave the system was measured by the undisturbed collection of sediments samplers, adapted by FIASP (1966), installed in the outcrop of the watersheds. For each measurement point, 4 samplers were installed per height, which consisted of repetitions. The sediment concentration considered was the average of the repetitions per height. The collections were made after precipitation in the study area above $12 \mathrm{~mm}$. Eight collectors were installed along the exit of the last sedimentation tank. The first sampling line corresponded to the minimum tank dimension and the second $0.1 \mathrm{~m}$ above. In the laboratory, the samples were weighed and carried to the oven at $105^{\circ} \mathrm{C}$ for $24 \mathrm{~h}$, obtaining the mass of 
sediments. These samples were accumulated, quantified and their granulometric composition were analyzed according to Donagema et al. (2011). The statistical design used was completely randomized and the results obtained were submitted to the normal analysis of the error distribution and homogeneity of error variances in computer environment R,Version 3.5.1 ( $\mathrm{R}$ Core Team, 2018).

The environmental services quantified in this study are related to water provision and sediment retention in the system. The quantification of the water provision was carried out through the climatological water balance of the small watersheds, the measured water demand and the quantification of the volumes of water stored in the system. The sediment quantification was based on the sediment-concentration data at sedimentation basins. The results of hydraulic conductivity, porosity and density were used as indicators of the initial condition of the land with respect to water provision.

\section{RESULTS AND DISCUSSION}

The GMH altimetric heights range from 40 to $200 \mathrm{~m}$, the slope is between 45 to $75 \%$ (mountainous relief). The flat areas add 2.7 ha of total area. The surface of flat curvature is predominant in $15 \%$ of the total area, the rest being dominated by the convex surface, with $62 \%$, followed by the concave, with $23 \%$. In the same way, the orientation of the slopes is variable, but with preponderance of the South and East faces. The hydrogenetic transmission zone represents $68 \%$ of the GMH, followed by the capitation zone $(20 \%)$ and outcrop zone $(12 \%)$.

Teodoro et al. (2007) states that the morphometric parameters of the watershed can be used as indicators of water flows and, consequently, the capacity of natural accumulation of water in the soil. The Dd indicates the drainage system efficacy (Rai et al., 2017), and represents the inverse relation of river length, where high values of drainage density are related to the small length of contributing tributaries. The average Dd of GMH and selected micro-basins was 2.2 $\mathrm{km} / \mathrm{km}^{2}$ showing medium drainage.

In this way, the studied watersheds have a predominance of horizontal flow and low capacity for water accumulation within the system. These results show that the area has a low natural water provision capacity, given that the watershed predominantly tends to flow superficially with the volume of precipitation received. This result agrees with that found by Bueno et al. (2019) who used the topographic index of humidity as indicator of water-producing areas and concluded that the study area has a low capacity for water provision.

The studied soil profiles presented relatively shallow surface horizons (10 to $15 \mathrm{~cm})$, with subsurface horizons with slow permeability and some profiles with close contact to the surface. The morphological, chemical and physical attributes of the profiles show that, in the hydrogenetic zones of capitation and transmission, there is occurrence of Oxisol (Latossolo Amarelo) (Santos et al., 2018). In addition, there is the presence of horizontal water flow due to the layer of impediment. In the outcrop zone, a Ultisols (Planossolo Nátricos) (Santos et al., 2018) was identified, resulting from the action of artificial drainage.

The mean total organic carbon values, in $\mathrm{kg}^{-1}$, were 4.94, 3.22, and 3.9, respectively, for capitation, transmission and outcrop zones. These values suggest that the whole area had low levels of organic matter, before the mining pit was dug. In addition, the low nutrient content is detrimental to the development of vegetative cover in deposition areas, which could act as a buffer to the direct impact of raindrops on the soil surface. This impact, with the subsequent destruction of the aggregates and their individualization, can cause superficial sealing of the surface layer, reducing the rate of infiltration of water in the soil and increasing the amount of sediments carried through surface runoff (Gonçalves and Moraes, 2012).

A significant difference was observed for the saturated hydraulic conductivity (CHS), at $5 \%$ probability by the $t$ test, while for the soil density and porosity no differences were observed 
in the hydrogenetic zones (Table 1). In the capitation and transmission zone, there was a reduction of 34 and $90 \%$ in the value of CHS, indicating the prevalence of horizontal flows of water in the soil, or subsurface flow.

The hydraulic conductivity can be considered as the ease with which the soil transmits water (Freitas et al., 2007), this way it is evident that the water flow tends to become horizontal flow. This fact is corroborated by the values of soil density that increase in depth and by the presence of pipes and horizons in which there is a lower hydraulic conductivity and layers of impediment, identified in the soil profile analysis.

Table 1. Soil hydraulic conductivity means for the different hydrogenetic zones and at three different depths.

\begin{tabular}{lccc}
\hline \multicolumn{4}{c}{ Soil hydraulic conductivity $*\left(\mathbf{m m h}^{-1}\right)$} \\
\hline \multirow{3}{*}{ hydrogenetic zones } & \multicolumn{3}{c}{ Soil depths $(\mathbf{c m})$} \\
\cline { 2 - 4 } & 15 & 40 & 70 \\
\hline Capitation & $134.60 \mathrm{aA}$ & $144.06 \mathrm{aA}$ & $88.77 \mathrm{aA}$ \\
Transmission & $287.40 \mathrm{aA}$ & $101.14 \mathrm{aB}$ & $29.10 \mathrm{aB}$ \\
Outcrop & $52.40 \mathrm{bA}$ & $34.20 \mathrm{aA}$ & $103.32 \mathrm{aA}$ \\
\hline *Values followed by different letters, lowercase in the column \\
and upper case in the row, indicate that the values differ from \\
each other (p <0.05), by the test of $t$ and $n s:$ not significant.
\end{tabular}

Thirteen $\mathrm{km}$ of drainage channels were mapped, followed by small sedimentation tanks, which directed the rainwater to the 11 main sedimentation tanks. Seven floodplain areas were mapped, with total storage capacity of up to $141,750 \mathrm{~m}^{3}$ of water. Considering the average density value proposed by Falcão and Ayres Neto (2010), the set of sedimentation tanks for the years 2012 to 2015 retained about $29,000 \mathrm{Mg}$ of sediment in the system. This result shows the efficiency of the measurement, which was also confirmed through the qualitative analysis of the effluent leaving the system.

The highest sediment concentration values (Table 2) measured in the river basin of the GMH were observed at the spillway level. Regarding the horizontal variation, the highest value was quantified in the central sampler. When analyzing the interaction between the mean sediment concentration and the value of the precipitated leaf in each sampling period, no significant differences were observed. The total sediment mass values for the samples were $13.91 \mathrm{~kg}, 13.60 \mathrm{~kg}, 20.04 \mathrm{~kg}, 13.74 \mathrm{~kg}$ and $43.94 \mathrm{~kg}$, respectively. These data show that, even in a period of full soil movement, the sediment export is very low and does not depend on precipitation volume.

The granulometric distribution of the solid sediments (Figure 2) varied in the direction of the inlet to the exit of the sedimentation tanks, and the sedimentation wedges near the entrance had wider diameters than those near the tank exudation. This pattern is due to the energy lost by the particles when being transported. As the energy decreases, the larger diameter particles begin to be deposited closer to the tank entrance, while the smaller ones are transported for longer distances (Palanques et al., 2009). Similarly, the horizontal distribution of the sediments may be correlated with the intensity of the rains, since the tanks receive sediments throughout the year, being emptied only in the dry period.

The visual analysis of the solid fraction of the sediments shows that they are mostly composed of primary minerals, highlighting the low values of total organic carbon in all layers. These results suggest that most of the accumulated sediment comes from the plowing area, in which there is constant movement of land. 
Table 2. Concentration of fine sediments, in $\mathrm{g} \mathrm{L}^{-1}$, for the 5 field collections.

\begin{tabular}{cc}
\hline Concentration of fine sediments & * , in $\mathbf{g L}^{-\mathbf{1}}$ \\
\hline Localization & Mean \\
\hline 1 & $2.04 \mathrm{c}$ \\
2 & $2.30 \mathrm{~b}$ \\
3 & $2.64 \mathrm{a}$ \\
4 & $2.34 \mathrm{~b}$ \\
\hline Height & Mean \\
\hline 1 & $3.22 \mathrm{a}$ \\
2 & $1.44 \mathrm{~b}$ \\
\hline
\end{tabular}

**Values followed by different letters, lowercase in the column and upper case in the row indicate that the values differ from each other ( $\mathrm{p}<0.05)$, by the test of $t$.

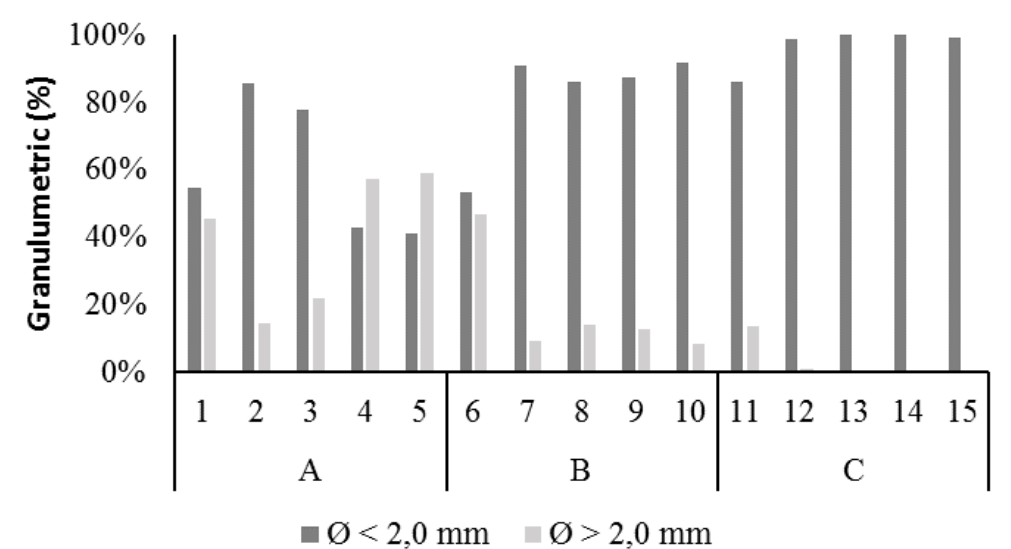

Figure 2. Percentage of variation of the diameter of the sediments accumulated along the sedimentation wedges of the tank. Sample block A represents the collection points closest to the tank inlet, $\mathrm{B}$ represents the center points and $\mathrm{C}$ the points closest to the tank outlet.

The actual water demand for the years 2012 to 2014 (Figure 3) shows a progressive increase over the years. The final balance of water provision in the GMH (Table 3) shows that there was supply of demand, even in periods when the climatological water balance was negative, in 2014.

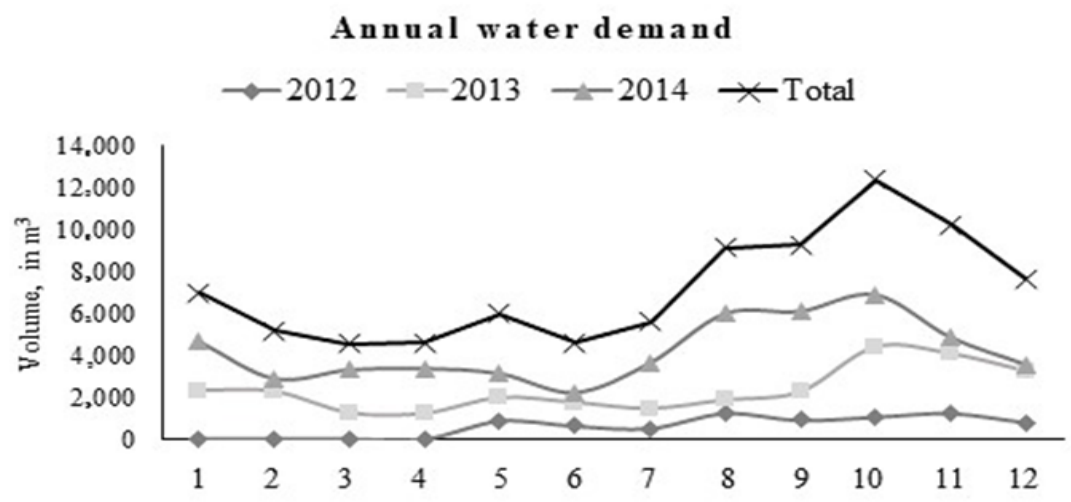

Figure 3. Water demand measured for the years 2012 to 2014 , in $\mathrm{m}^{3}$. 
Table 3. Final balance of water provision before and after the implementation of the measures that empower environmental services.

\begin{tabular}{lcccc}
\hline Item $\left(\mathbf{m}^{\mathbf{3}}\right)$ & $\mathbf{2 0 1 1}$ & $\mathbf{2 0 1 2}$ & $\mathbf{2 0 1 3}$ & $\mathbf{2 0 1 4}$ \\
\hline Climatological water balance & $-129.813,99$ & $7,222.18$ & $243,801.22$ & $-219,735.00$ \\
Storage capacity & - & $227,333.00$ & $238,699.65$ & $281,892.92$ \\
Precipitation & $709,194.42$ & $875,157.36$ & $1,082,207.50$ & $685,275.80$ \\
Capture for industrial use & - & $7,355.60$ & $28,153.00$ & $50,567.00$ \\
\hline Final balance & $-129,813.99$ & $227,199.58$ & $454,347.87$ & $11,590.92$ \\
\hline
\end{tabular}

The final balance shows that the potential evapotranspiration is greater than the precipitated blade for the years 2011 and 2014; meanwhile, in 2012, these values are practically the same. Thus, in normal conditions, the GMH would not have the capacity to supply water for the activities developed, even considering the use of all precipitated water, which would not support industrial activity.

However, the installed water collection, storage and distribution system shows that there was an inversion of the natural tendency of the water flow, allowing rainwater to remain in the system for longer and reducing water volume loss through evapotranspiration. In this way, actions should be directed towards ecosystems capable of improving the use of water resources, allowing the feasibility of the proposed activities, promoting the economic and social development of areas that, due to lack of water, would not have this capacity. The environmental services offered by a watershed in an anthropic transformation process are related to the maintenance of positive water balance and sediment retention in the system.

\section{CONCLUSIONS}

The studied watersheds demonstrate low natural capacity to provincial environmental services related to water resources. The continuous and irregular use of the area has decreased water availability in these areas. Consequently, the climatic water balance is negative, since the potential evapotranspiration is greater than or equal to the precipitated leaf. The identification of areas with water storage capacity and recirculation processes allowed the resource to remain in the system, contributing to the environmental and economic feasibility of the proposed activities.

Therefore, a model of water production and sediment contention, based on the identification of the mature ecosystems and the implementation of a system of abstraction, directing and subsurface storage of rainwater and recirculation of surpluses, has proven to be efficient and can be used as an important tool management of environmental services.

\section{ACKNOWLEDGEMENTS}

We thank the Federal Rural University of Rio de Janeiro, specifically the PPGCAF, LMBH and LGCS. We recognize CNPq and the Petra Agregados mining company for the financial support. This study was financed in part by the Coordenação de Aperfeiçoamento de Pessoal de Nível Superior - Brasil (CAPES) - Finance Code 001.

\section{REFERENCES}

ALVARES, C. A.; STAPE, J. L.; SENTELHAS, P. C.; DE MORAES, G.; LEONARDO, J.; SPAROVEK, G. Köppen's climate classification map for Brazil. Meteorologische Zeitschrift, v. 22, n. 6, p. 711-728, 2013. https://doi.org/10.1127/0941-2948/2013/0507 
BARBAN, V. Fórum Mundial da Água-questões fundamentais e muitas controvérsias. REDDRevista Espaço de Diálogo e Desconexão, v. 1, n. 2, 2009.

BUENO, M. M.; VALCARCEL, R.; MATEUS, F. A.; PEREIRA, M. G. Environmental services in watersheds with small declivity: fluvial marine plains. Revista Ambiente \& Água, v. 14, n. 3, p. 1-11, 2019. https://doi.org/10.4136/ambi-agua.2265

CHRISTOFOLETTI, A. Geomorfologia. 2. ed. São Paulo: Edgard Blücher, 1980. 188 p.

COOK, B. R.; SPRAY, C. J. Ecosystem services and integrated water resource management: Different paths to the same end? Journal of Environmental Management, v. 109, p. 93-100, 2012. https://doi.org/10.1016/j.jenvman.2012.05.016

DONAGEMA, G. K.; CAMPOS, D. D.; CALDERANO, S. B.; TEIXEIRA, W. G.; VIANA, J. H. M. Manual de métodos de análise de solos. Rio de Janeiro: Embrapa Solos, 2011. $230 \mathrm{p}$.

FALCÃO, L. C.; AYRES NETO, A. Parâmetros físicos de sedimentos marinhos superficiais da região costeira de Caravelas, sul da Bahia. Revista Brasileira de Geofísica, v. 28, n. 2, p. 279-289, 2010. https://doi.org/10.1590/S0102-261X2010000200011

FIASP. A study of methods used in measurement and analysis of sediment loads instreams. Minnesota: Anthony Falls Hydraulic Lab. Minneapolis, 1966.

FREITAS, M. D. G. B.; MESQUITA, S. O. M.; PERUCHI, F.; DE CARVALHO TEREZA, M. Alternativa para caracterização da condutividade hidráulica saturada do solo utilizando probabilidade de ocorrência. Ciência e Agrotecnologia, v. 31, n. 6, 2007. https://doi.org/10.1590/S1413-70542007000600001

GNADLINGER, J. How can rainwater harvesting contribute to living with droughts and climate change in semi-arid Brazil? Waterlines, v. 33, n. 2, p. 146-153, 2014. www.jstor.org/stable/24688145

GONÇALVES, F. C.; MORAES, M. H. Porosidade e infiltração de água do solo sob diferentes sistemas de manejo. Irriga, v. 17, n. 3, p. 337, 2012. https://doi.org/10.15809/irriga.2012v17n3p337

HAJAM, R. A.; HAMID, A.; BHAT, S. Application of morphometric analysis for geohydrological studies using geo-spatial technology - A case study of Vishav drainage watershed. Hydrology Current Research, v. 4, n. 3, p. 1-12, 2013. http://dx.doi.org/10.4172/2157-7587.1000157

HATTERMANN, F. F.; KRYSANOVA, V.; HABECK, A.; BRONSTERT, A. Integrating wetlands and riparian zones in river basin modelling. Ecological modelling, v. 199, n. 4, p. 379-392, 2006. https://doi.org/10.1016/j.ecolmodel.2005.06.012

PALANQUES, A.; PUIG, P.; LATASA, M.; SCHAREK, R. Deep sediment transport induced by storms and dense shelf-water cascading in the northwestern Mediterranean basin. Deep Sea Research Part I: Oceanographic Research Papers, v. 56, n. 3, p. 425-434, 2009. https://doi.org/10.1016/j.dsr.2008.11.002

RAI, P. K.; MOHAN, K.; MISHRA, S.; AHMAD, A.; MISHRA, V. N. A GIS-based approach in drainage morphometric analysis of Kanhar River Basin, India. Applied Water Science, v. 7, n. 1, p. 217-232, 2017. https://doi.org/10.1007/s13201-014-0238-y

R CORE TEAM. R: a language and environment for statistical computing. Vienna: $\mathrm{R}$ Foundation for Statistical Computing, 2018. 
SANTOS, H. G. dos et al. Sistema Brasileiro de Classificação dos Solos. 5. ed. Brasília: Embrapa, 2018. 356 p.

TEODORO, V. L. I.; TEIXEIRA, D.; COSTA, D. J. L.; FULLER, B. B. O conceito de bacia hidrográfica e a importância da caracterização morfométrica para o entendimento da dinâmica ambiental local. Revista Brasileira Multidisciplinar, v. 11, n. 1, p. 137-156, 2007. https://doi.org/10.25061/2527-2675/ReBraM/2007.v11i1.236 